\title{
Elution of Exocellular Enzymes from Saccharomyces fragilis and Saccharomyces cerevisiae
}

\author{
RALPH WEIMBERG ${ }^{1}$ AND WILLIAM L. ORTON \\ Pioneering Laboratory for Microbiological Chemistry, Northern Regional Research Laboratory, \\ U.S. Department of Agriculture, Peoria, Illinois
}

Received for publication 28 August 1965

\begin{abstract}
Weimberg, RalPh (Northern Regional Research Laboratory, Peoria, III.), AND WiLliam L. ORTON. Elution of exocellular enzymes from Saccharomyces fragilis and Saccharomyces cerevisiae. J. Bacteriol. 91:1-13. 1966.-Invertase and acid phosphatase are repressible exocellular enzymes in Saccharomyces fragilis and $S$. cerevisiae. The conditions for eluting these enzymes from both organisms were compared. Either $\mathrm{KCl}$ or $\beta$-mercaptoethanol eluted the enzymes from $S$. fragilis, and the amounts eluted varied quantitatively according to the physiological age of the organism. In addition to eluting enzymatic activity from the cells, these reagents also caused a large increase in the amount of activity that remained associated with the cells of $S$. fragilis. Invertase and acid phosphatase were not removed from cells of $S$. cerevisiae by $\mathrm{KCl}$ or $\beta$-mercaptoethanol. These enzymes were separated from $S$. cerevisiae cells only when there was some degree of cell-wall digestion by snail gut fluid.
\end{abstract}

During the process of protoplast formation of Saccharomyces cerevisiae, invertase and acid phosphatase were released from the cells and recovered as soluble enzymes $(9,16)$. This result was accepted as proof that these two enzymes are exocellularly located (i.e., outside the cell membrane but bound to the cell). $S$. mellis was also found to contain an active acid phosphatase (18) that was shown to be an exocellular enzyme by use of this same kind of evidence (19). Subsequently, it was reported that elution of the enzyme is not necessarily related to protoplast formation. Acid phosphatase may be removed from cells in a reaction mixture containing the ancillary reagents for protoplast formation $(\mathrm{KCl}$ and $\beta$-mercaptoethanol) but lacking the enzyme system that digests the cell wall (20). In some respects, this method of removing acid phosphatase from $S$. mellis resembled the elution of exocellular enzymes from Escherichia coli (10). $S$ mellis is an osmophile (a group of yeasts capable of growing in high concentrations of sugar), and, possibly, the organism's reaction to these reagents might be different from that of $S$. cerevisiae or other yeasts not considered to be osmophilic Therefore, the conditions under which exocellular enzymes may be eluted from $S$. cerevisiae were

${ }^{1}$ Present address: U.S. Salinity Laboratory, Riverside, Calif. studied to determine whether it was necessary to convert the cells into protoplasts to achieve dissociation of the enzymes from the cells, or whether the enzymes could be removed in a manner analogous to that described for $S$. mellis.

For comparison, since $S$. mellis does not have invertase activity, another yeast organism was sought that was sufficiently different from both $S$. cerevisiae and $S$. mellis but that still possessed acid phosphatase and invertase activity. $S$. fragilis was found to fit these requirements. It should be noted, though, that the invertases of $S$. fragilis and baker's yeast are $\beta$-fructosidases that differ from one another in specificity properties (14, 15). Methods for eluting exocellular enzymes from cells of this organism were also studied. The conditions for elution were not only distinctly different for each of these two organisms, $S$. cerevisiae and $S$. fragilis, but the conditions differed from those described for the elution of enzymes from $S$. mellis.

\section{Materials AND Methods}

The yeasts used, $S$. fragilis NRRL Y-665 and S. cerevisiae NRRL Y-567, were obtained from L. J. Wickerham of the Northern Regional Research Laboratory. $S$. fragilis was grown in a medium containing $1 \%$ glucose, $0.5 \%$ yeast extract (free from inorganic phosphate), and $0.1 \%$ urea. The yeast extract was treated with magnesia to remove the inorganic 
phosphate (18). S. cerevisiae grew poorly in this medium. However, cells of $S$. cerevisiae that were derepressed for acid phosphatase could be obtained in good yield when the yeast extract of the medium described was not treated but used as commercially supplied. Both organisms were grown at $28 \mathrm{C}$ under aerobic conditions by placing a 2.6-liter Fernbach flask, containing $200 \mathrm{ml}$ of inoculated medium, on a reciprocal shaker oscillating at a rate of 100 strokes per minute through a distance of 2 inches $(5.08 \mathrm{~cm})$.

Invertase activity was determined by measuring the amount of reducing sugar formed from sucrose during $10 \mathrm{~min}$ of incubation at $30 \mathrm{C}$ in a reaction mixture containing $0.05 \mathrm{ml}$ of $0.1 \mathrm{M}$ sucrose, $0.05 \mathrm{ml}$ of $1.0 \mathrm{M}$ acetate buffer $(p H 5.5), 0.2 \mathrm{ml}$ of water, and $0.2 \mathrm{ml}$ of the enzyme source. The concentration of enzyme or cells in this reaction mixture was adjusted so that no more than $50 \%$ of the substrate was hydrolyzed in the 10-min period. Acid phosphatase activity was assayed by measuring the amount of inorganic phosphate formed when a mixture containing the following (in milliliters) was incubated at $30 \mathrm{C}$ for $10 \mathrm{~min}$ : $0.1 \mathrm{M}$ sodium pyrophosphate, $0.05 ; 1.0 \mathrm{M}$ acetate buffer, 0.2 ; water, 0.15 ; and the enzyme source, 0.2 . If the enzyme source was the $S$. fragilis system, both substrate and buffer were adjusted to $\mathrm{pH} 6.5$ (which is the optimal $p \mathrm{H}$ for the reaction catalyzed by the enzyme from $S$. fragilis), and the concentration of supernatant fluid or cells was such that less than one-third of the pyrophosphate was hydrolyzed in $10 \mathrm{~min}$. However, if the enzyme source was $S$. cerevisiae, the $p \mathrm{H}$ of the reaction mixture was adjusted to 3.5 , since the $p \mathrm{H}$ optimum of the acid phosphatase of $S$. cerevisiae was approximately 3 . The concentration of supernatant fluid or cells in the reaction mixture was not overly critical as long as no more than twothirds of the substrate was hydrolyzed in the allotted time period. Under the conditions described above for invertase and acid phosphatase assays, the rates of the reactions were constant with time and were directly proportional to enzyme concentration. Activity of both enzymes is expressed as the amount of product formed in $10 \mathrm{~min}$ at $30 \mathrm{C}$ by $1 \mathrm{ml}$ of a suspension of cells or $1 \mathrm{ml}$ of the supernatant fluid of a reaction mixture.

Reducing sugar was measured as described by Park and Johnson (12). Inorganic phosphate was determined by the method of Taussky and Shorr (17). Protein and total carbohydrate were measured by use of Folin-Ciocalteu (8) and anthrone (6) reagents, respectively. All chemicals and reagents were obtained from commercial sources.

\section{Results}

Elution of acid phosphatase and invertase from $S$. fragilis. Results of experiments in which $S$. fragilis was grown in media to which phosphate was added or omitted, and to which glucose or some other organic compound was supplied as carbon source, indicated that both acid phosphatase and invertase are repressible enzymes. Also, they are exocellularly located as will be shown in the experiments that follow. It would be convenient to study the elution of these en- zymes at a time when both enzymes were present on the cell simultaneously. In the medium used in this study for growing $S$. fragilis, in which the carbon source was glucose, this condition existed only after the cells were in the maximal stationary phase of growth owing to exhaustion of substrate Therefore, all experiments to be reported were performed with cells that were in this stage of the growth cycle, except where indicated otherwise.

Cells in the maximal stationary phase were selected for this study for another reason. The firmness with which the enzymes were held on the cell surface varied with physiological age (Table 1). Snail gut fluid, which contains the enzyme system that digests yeast cell walls, is required to remove acid phosphatase from cells still in the log phase of growth. Although some phosphatase is eluted by salt and thiol alone after $6 \mathrm{hr}$ of incubation, the amount is small compared with that still associated with the cell. Considerably more activity can be released from cells in the maximal stationary phase by $\mathrm{KCl}$ and $\beta$-mercaptoethanol in reaction mixtures lacking snail fluid in respect to both the amount of activity still attached to the cells and the amount solubilized in the same length of time in reaction mixtures containing snail fluid. Also, the longer the cells are incubated in growth media after reaching maximal growth (i.e., allowed to "age"), the greater the apparent rate of elution of enzymatic activity under any one set of conditions. The data on acid phosphatase activity in Table 1 are of qualitative value only, since the eluates were not assayed under conditions that would reveal total activity (see Tables 2, 3, and 4). In both log-phase and early maximal stationary-phase cells, $30 \%$ of the invertase activity present initially on the cell can be recovered in the soluble fraction after $6 \mathrm{hr}$ of incubation in reaction mixtures containing salt and thiol but lacking snail extract. However, when the amount of invertase extracted by salt plus thiol is compared to that eluted by snail fluid in conjunction with these two reagents, significant differences are apparent between cells harvested during log phase and those harvested after completion of growth. Omitting snail extract from the reaction mixtures resulted in the elution of 40 and $80 \%$ of the invertase activity from log-phase and maximal stationary-phase cells, respectively, of that recovered as soluble enzyme when snail fluid was included. Thus, the mechanism of invertase attachment to the cell surface seems to vary with cell age, also. Therefore, to obtain reproducible results, all studies were done with cells from cultures from which the substrate had been exhausted for no more than 2 hr. This condition was accomplished by inoculating growth media, containing $1 \%$ glucose, with a $2 \%$ volume of a fully grown culture of $S$. fragilis 


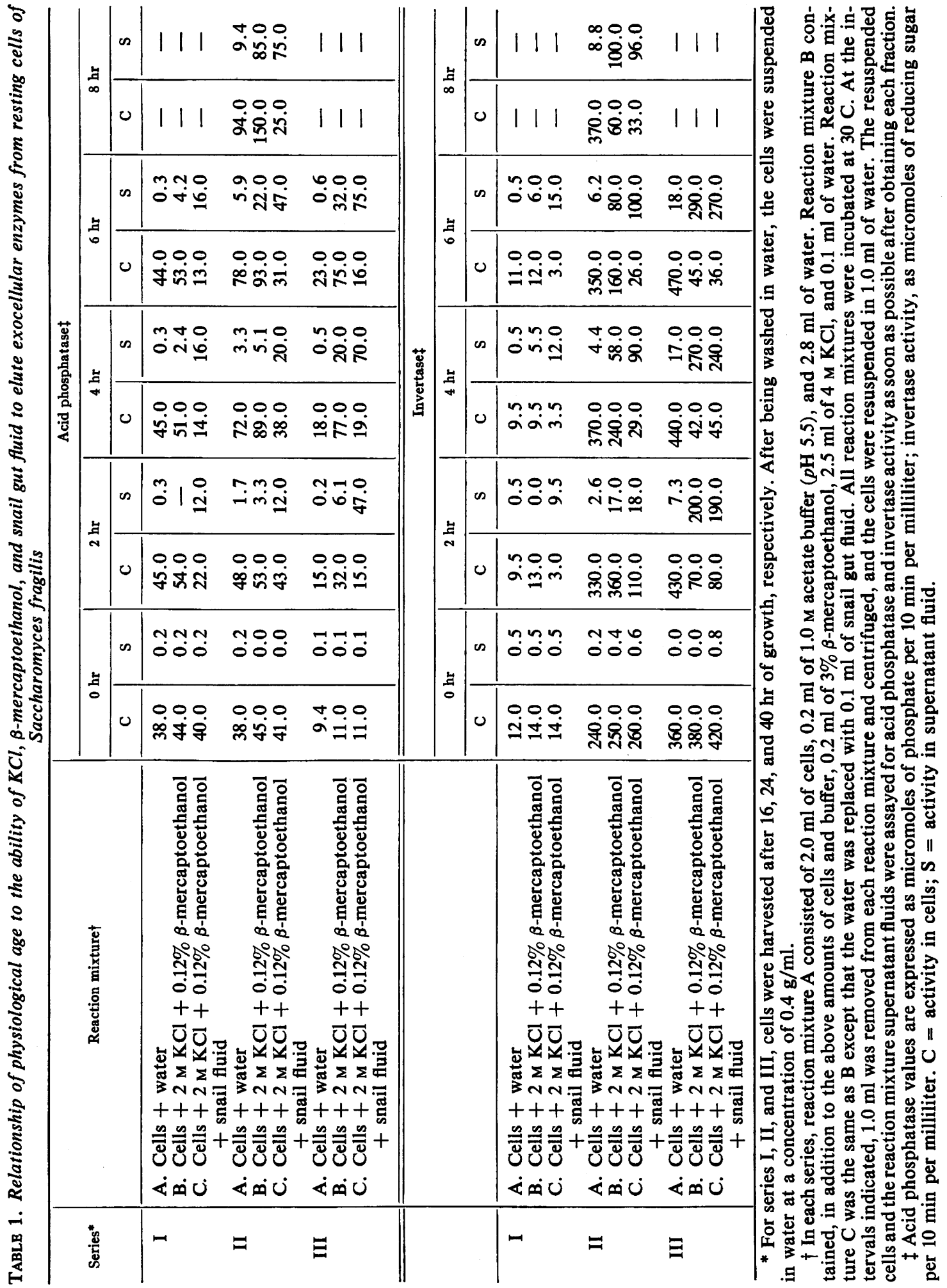


and incubating the media aerobically at $28 \mathrm{C}$ for $24 \mathrm{hr}$.

It is not believed that release of activity from "old" cells (cells in the maximal stationary phase) in the absence of snail extract is due to breakdown of cell structure or loss of selective cell permeability. $S$. fragilis cells were severely dehydrated when suspended in the high concentrations of salt used in this work, but they regained their normal turgid morphology when centrifuged and resuspended in water. Furthermore, microscopic examination revealed no lysed forms.

Acid phosphatase was eluted from cells of $S$. mellis either with $2.0 \mathrm{M} \mathrm{KCl}$ plus $0.3 \% \beta$-mercaptoethanol or with $0.5 \mathrm{M} \mathrm{KCl}$ alone (20). Neither $2.0 \mathrm{M} \mathrm{KCl}$ alone nor $\beta$-mercaptoethanol at any concentration eluted activity. When $S$. fragilis cells were treated similarly, quite different results were obtained. The data show (Table 1, section II; Tables 2 and 3) that these reagents were not needed for enzyme elution. Merely suspending resting cells in buffer was adequate for this purpose; however, the rate at which acid phosphatase and invertase are separated from the cells was increased if $\mathrm{KCl}$ and $\beta$-mercaptoethanol, either separately or together, were included in the reaction mixture. The effect of various concentrations of thiol on the rate of enzyme elution is reported in Table 2. Not all the acid phosphatase extracted was detectable if the eluates were assayed immediately. Storage of the eluates at $5 \mathbf{C}$ resulted in significant increases in the amount of activity present. On the other hand, invertase activity remained relatively constant. The phosphatase activity of the cells increased greatly at all concentrations of $\beta$-mercaptoethanol, even though activity was also appearing in the supernatant fluid at the same time.

Total activity for both enzymes in the reaction mixture supernatant fluids increased with increasing thiol concentrations up to $0.5 \% \beta$-mercaptoethanol. There did not seem to be any concentration that clearly favored the dissociation of one enzyme over the other or even elution of protein in relation to carbohydrate. At $1 \%$ thiol, the ratio of acid phosphatase activity to invertase dropped to $1: 1$. Since the amount of protein eluted was even greater than at lower thiol concentrations, it would appear that there is some inactivation of acid phosphatase rather than favored elution of invertase.

Other compounds may substitute for $\beta$-mercaptoethanol in this system; $\mathrm{Na}_{2} \mathrm{~S}$, as well as most organic mercaptans, was equally as effective. Potassium cyanide and sodium bisulfite were also satisfactory for this purpose. Although 2,3dimercapto-1-propanol and ascorbate could stim- ulate invertase elution, these two reagents inactivated acid phosphatase.

Ionic compounds also eluted the two enzymes from $S$. fragilis cells. When $\mathrm{KCl}$ was used, the optimal concentration of salt for the most rapid rate of elution of invertase was around $0.2 \mathrm{M}$, whereas the concentration most suitable for elution of acid phosphatase was higher at $1.0 \mathrm{M}$ (Table 3 ). Even though enzymatic activity appeared in the supernatant fluid of the reaction mixtures, there was an increase in acid phosphatase activity in the cells. This increase appears to be independent of the salt concentration up to $1.0 \mathrm{M} \mathrm{KCl}$. The amount of invertase activity on the cells remained relatively constant regardless of the amount of this enzyme extracted.

Eluates from cells incubated in the presence of $\mathrm{KCl}$ possessed little acid phosphatase activity in relation to the amount initially detected on the cells if they were assayed immediately (Table 3 ). However, if the eluates were first incubated for several hours and then assayed, the activity present increased sharply. Furthermore, if $\beta$-mercaptoethanol was added to the eluate, both the rate and degree of change of enzymatic activity increased even more. The results suggest that the enzyme was released from the cells in an inactive form and that, once separated from the cells, it was altered in some way to become a functional enzyme. Specific activities were not calculated from data in Table 3 since the time period of the experiment was not long enough for the eluates to reach their highest activity. Approximately $16 \mathrm{hr}$ was required to elute all the enzyme that can be extracted by $1.0 \mathrm{M} \mathrm{KCl}$, and nearly $24 \mathrm{hr}$ was needed for the eluate to reach maximal activity (Table 4). One peculiar feature of this system was that the increase in activity in the eluates (after removal of cells) was much greater than in the reaction mixtures still containing cells and incubated the same length of time.

Neu and Heppel (10) recently reported the removal of several enzymes from the surface of Escherichia coli by first suspending the cells in $20 \%$ sucrose and then washing them with cold water. In constrast, the acid phosphatase of $S$. mellis could not be eluted with cold water after treatment of the cells with either sucrose or salt (20). It was decided to determine which system, if any, $S$. fragilis resembled. The results with $S$. fragilis varied with the physiological age of the organism. In cells from cultures that had reached maximal growth, but that were allowed to age by incubation aerobically for an additional 6 or 12 hr before harvesting, the two enzymes were extractable in significant amounts by a cold-water wash after a brief exposure (5 to $15 \mathrm{~min}$ ) of the 


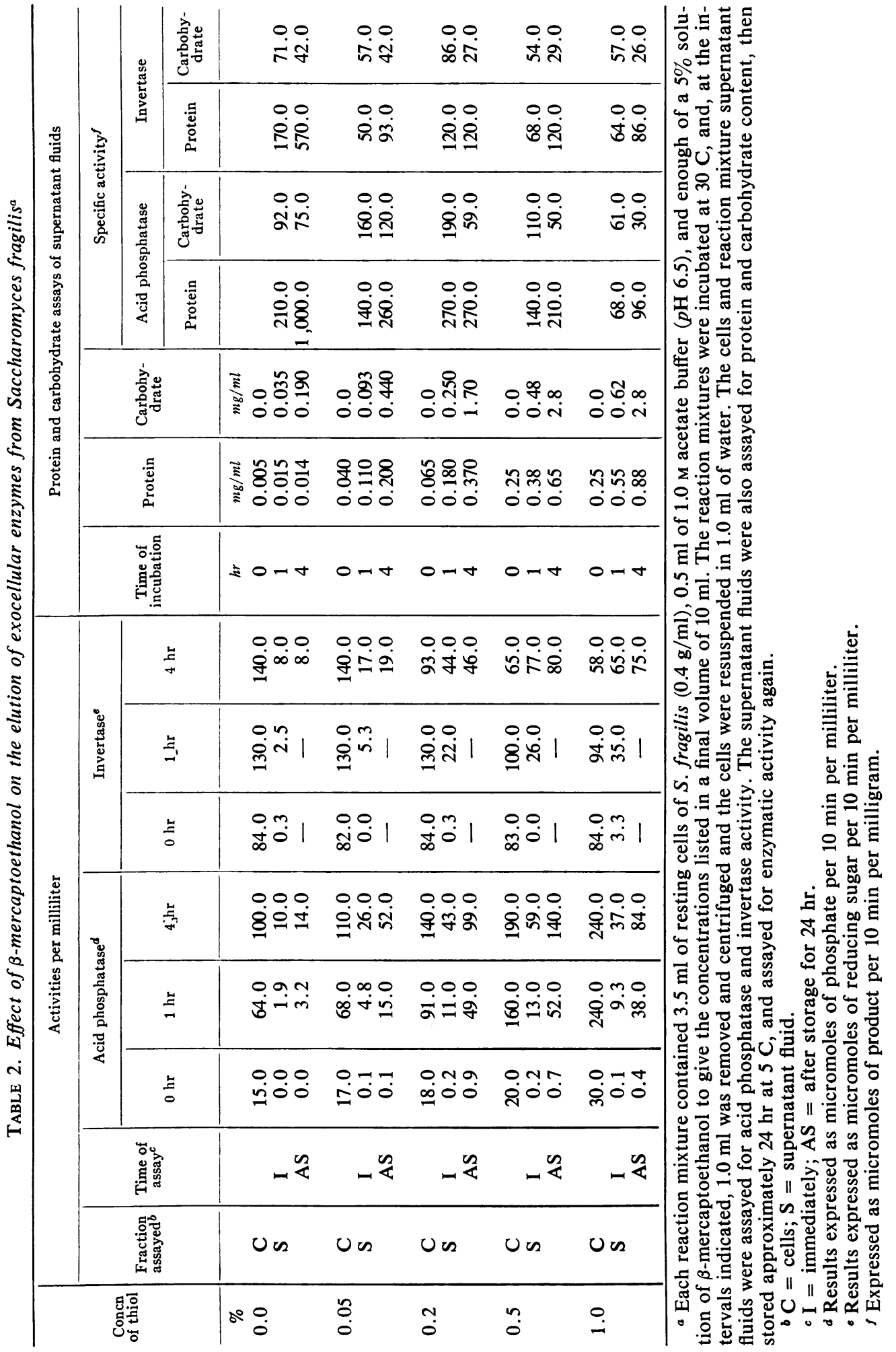


TABLE 3. Effect of $\mathrm{KCl}$ on the elution of exocellular enzymes from Saccharomyces fragilis ${ }^{a}$

\begin{tabular}{|c|c|c|c|c|c|c|c|c|c|c|c|c|c|}
\hline \multirow{3}{*}{$\begin{array}{c}\text { Concn } \\
\text { of } \\
\mathrm{KCl}\end{array}$} & \multicolumn{10}{|c|}{ Activities per milliliter } & \multicolumn{3}{|c|}{$\begin{array}{l}\text { Protein and carbohy- } \\
\text { drate assay of super- } \\
\text { natant fluids }\end{array}$} \\
\hline & \multirow{2}{*}{$\begin{array}{l}\text { Fraction } \\
\text { assayed }^{b}\end{array}$} & \multirow{2}{*}{$\begin{array}{l}\text { Time of } \\
\text { assay }\end{array}$} & \multicolumn{4}{|c|}{ Acid phosphatase $^{c}$} & \multicolumn{4}{|c|}{ Invertase $^{d}$} & \multirow{2}{*}{$\begin{array}{c}\text { Time of } \\
\text { incuba- } \\
\text { tion }\end{array}$} & \multirow{2}{*}{ Protein } & \multirow{2}{*}{$\begin{array}{c}\text { Carbo- } \\
\text { hydrate }\end{array}$} \\
\hline & & & $0 \mathrm{hr}$ & $1 \mathrm{hr}$ & $4 \mathrm{hr}$ & $6 \mathrm{hr}$ & $0 \mathrm{hr}$ & $1 \mathrm{hr}$ & $4 \mathrm{hr}$ & $6 \mathrm{hr}$ & & & \\
\hline \multirow{6}{*}{$0^{M}$} & & & & & & & & & & & $h r$ & $m g / m l$ & $m g / m l$ \\
\hline & $\mathrm{C}$ & & 27.0 & 45.0 & 68.0 & 73.0 & 150.0 & 160.0 & 160.0 & 150.0 & 0 & 0.024 & 0.014 \\
\hline & $\mathbf{s}+\mathbf{w}$ & Initial & 0.1 & 2.2 & 5.7 & 9.6 & 0.0 & 3.8 & 12.0 & 15.0 & 4 & 0.20 & 0.34 \\
\hline & S T & Plus 2 hr & 0.1 & 8.6 & 44.0 & - & & & & & & & \\
\hline & $\mathbf{S}+\mathbf{T}$ & Initial & 0.1 & 2.2 & 5.5 & 11.0 & & & & & & & \\
\hline & & Plus $2 \mathrm{hr}$ & 0.1 & 22.0 & 100.0 & 一 & & & & & & & \\
\hline \multirow[t]{5}{*}{0.2} & $\mathrm{C}$ & & 38.0 & 63.0 & 64.0 & 64.0 & 180.0 & 170.0 & 160.0 & 160.0 & 0 & 0.008 & 0.032 \\
\hline & $\mathbf{S}+\mathbf{w}$ & Initial & 0.1 & 2.2 & 4.6 & 5.6 & 0.8 & 20.0 & 49.0 & 55.0 & 4 & 0.17 & 0.28 \\
\hline & & Plus 2 hr & 0.0 & 15.0 & 37.0 & - & & & & & & & \\
\hline & $\mathbf{S}+\mathbf{T}$ & Initial & 0.0 & 2.1 & 5.1 & 6.8 & & & & & & & \\
\hline & & Plus 2 hr & 0.0 & 28.0 & 69.0 & - & & & & & & & \\
\hline \multirow[t]{5}{*}{0.5} & $\mathrm{C}$ & & 40.0 & 63.0 & 62.0 & 57.0 & 220.0 & 210.0 & 190.0 & 190.0 & 0 & 0.002 & 0.021 \\
\hline & $\mathbf{S}+\mathbf{w}$ & Initial & 0.1 & 1.9 & 3.5 & 6.6 & 0.6 & 18.0 & 49.0 & 50.0 & $\begin{array}{l}1 \\
4\end{array}$ & 0.25 & 0.42 \\
\hline & & Plus $2 \mathrm{hr}$ & 0.1 & 19.0 & 64.0 & - & & & & & & & \\
\hline & $\mathbf{S}+\mathbf{T}$ & Initial & 0.1 & 1.8 & 3.4 & 5.8 & & & & & & & \\
\hline & & Plus $2 \mathrm{hr}$ & 0.1 & 41.0 & 120.0 & - & & & & & & & \\
\hline \multirow[t]{5}{*}{1.0} & $\mathrm{C}$ & & 25.0 & 37.0 & 44.0 & 39.0 & 160.0 & 160.0 & 160.0 & 150.0 & 0 & 0.020 & 0.080 \\
\hline & $\mathbf{S}+\mathbf{w}$ & Initial & 0.0 & 3.6 & 10.0 & 17.0 & 0.8 & 13.0 & 41.0 & 55.0 & $\begin{array}{l}1 \\
4\end{array}$ & 0.47 & 0.85 \\
\hline & & Plus $2 \mathrm{hr}$ & 0.0 & 25.0 & 100.0 & - & & & & & & & \\
\hline & $\mathbf{S}+\mathbf{T}$ & Initial & 0.0 & 3.6 & 9.6 & 16.0 & & & & & & & \\
\hline & & Plus $2 \mathrm{hr}$ & 0.0 & 46.0 & 170.0 & - & & & & & & & \\
\hline \multirow[t]{5}{*}{2.0} & $\mathrm{C}$ & & 33.0 & 140.0 & 170.0 & 190.0 & 240.0 & 210.0 & 210.0 & 220.0 & 0 & 0.040 & 0.025 \\
\hline & $\mathbf{S}+\mathbf{w}$ & Initial & 0.0 & 2.8 & 11.0 & 15.0 & 0.2 & 3.8 & 11.0 & 15.0 & 4 & 0.21 & 0.42 \\
\hline & & Plus $2 \mathrm{hr}$ & 0.0 & 28.0 & 110.0 & - & & & & & & & \\
\hline & $\mathbf{S}+\mathbf{T}$ & Initial & 0.1 & 2.1 & 11.0 & 18.0 & & & & & & & \\
\hline & & Plus $2 \mathrm{hr}$ & 0.1 & 31.0 & 130.0 & - & & & & & & & \\
\hline
\end{tabular}

a Each reaction mixture contained $15 \mathrm{ml}$ of cells $(0.4 \mathrm{~g} / \mathrm{ml}), 2 \mathrm{ml}$ of $1.0 \mathrm{M}$ acetate buffer $(p \mathrm{H} 6.5)$, and enough $4 \mathrm{M} \mathrm{KCl}$ and water to give the concentrations listed in a total volume of $40 \mathrm{ml}$. The reaction mixtures were incubated at $30 \mathrm{C}$, and, at the intervals indicated, $4.0 \mathrm{ml}$ was removed and centrifuged, and the cells were resuspended in $4.0 \mathrm{ml}$ of water. The supernatant fluid of each sample was divided into two portions of $1.5 \mathrm{ml}$ each. To one portion was added $0.15 \mathrm{ml}$ of water, and to the other portion was added $0.15 \mathrm{ml}$ of $3 \% \beta$-mercaptoethanol. These two supernatant reaction mixtures were replaced in a $30 \mathrm{C}$ water bath and incubated for the additional period of time indicated. The residual supernatant fluid was used for an invertase assay. The two treated supernatant fractions were used for acid phosphatase activity determinations. Also, invertase and acid phosphatase activities of the resuspended cells were measured.

${ }^{b} \mathbf{C}=$ cells $; \mathbf{S}=$ supernatant fluid; $\mathbf{W}=$ water $\mathbf{T}=$ thiol.

${ }^{c}$ Results expressed as micromoles of phosphate per 10 min per milliliter.

${ }^{d}$ Results expressed as micromoles of reducing sugar per 10 min per milliliter.

cells to $1 \mathrm{M} \mathrm{KCl}$. Furthermore, with continued incubation for periods up to 3 days, a point was reached where enzymatic activity could be detected in growth media, and the enzymes that were still attached to the cells could be removed by water after the cells had been washed in dilute buffer. However, in cells at the physiological age used in the previous experiments, the cell surface 


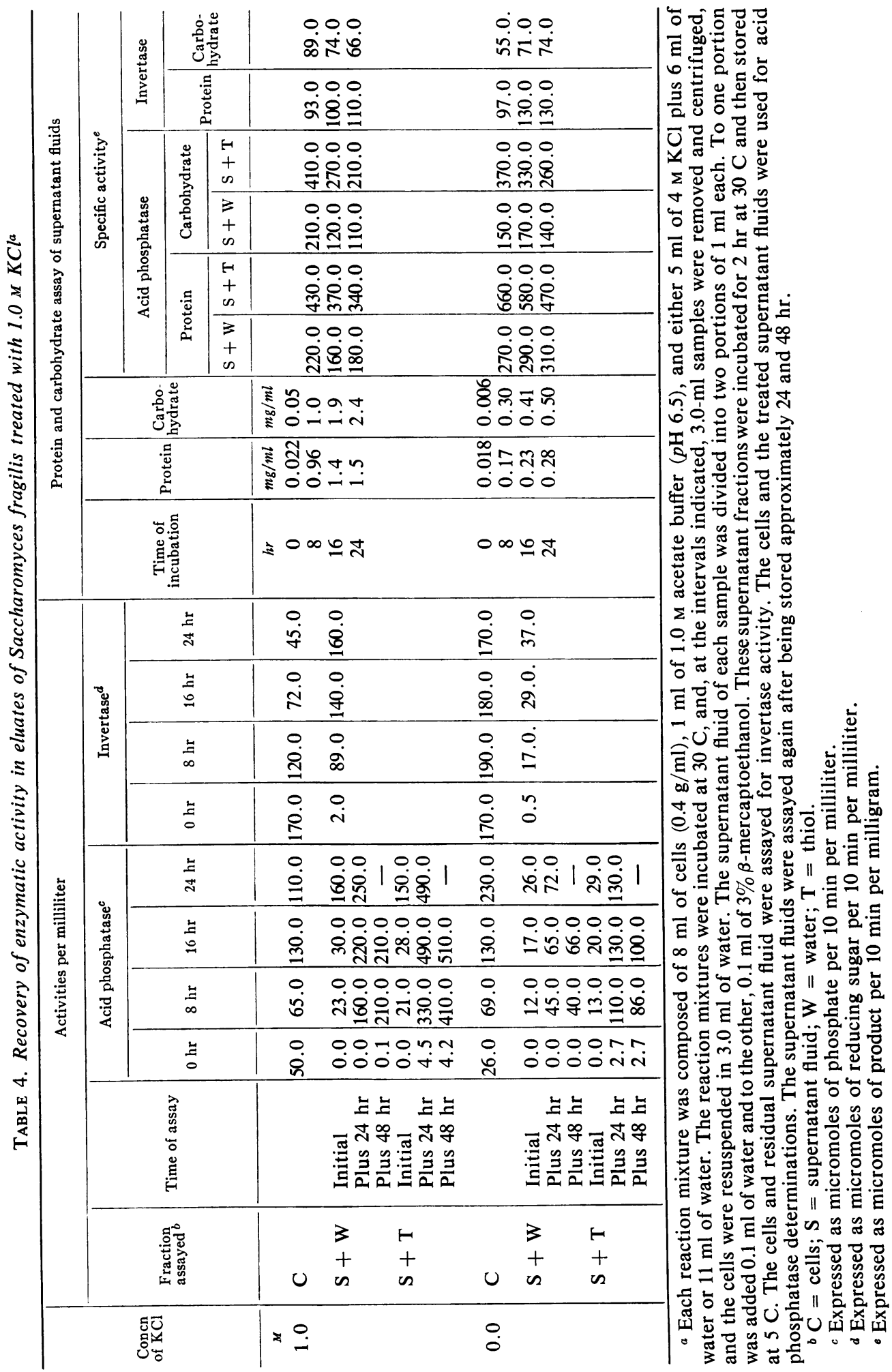




\begin{tabular}{|c|c|c|c|c|c|c|}
\hline \multirow{7}{*}{ 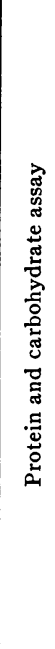 } & \multirow{3}{*}{ 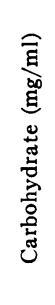 } & $\stackrel{\mu}{g}$ & 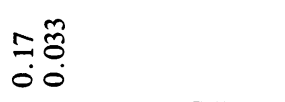 & $\begin{array}{l}\infty \\
\infty \\
0 \\
0\end{array}$ & \multicolumn{2}{|l|}{ श्री } \\
\hline & & $\stackrel{\underline{E}}{=}$ & $\begin{array}{l}\infty \\
\vdots \\
\vdots \\
0 \\
0\end{array}$ & ก๋ & \multicolumn{2}{|l|}{ กิ } \\
\hline & & 点 & $\because \div$ & $\begin{array}{l}\hat{8} \tilde{8} \\
0 \\
0 \\
0\end{array}$ & \multicolumn{2}{|l|}{ mọ } \\
\hline & \multirow{3}{*}{ 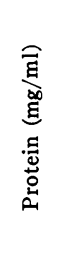 } & $\stackrel{\text { s }}{f}$ & \begin{tabular}{l} 
\pm 0 \\
\hdashline 0 \\
0
\end{tabular} & $\begin{array}{l}\infty \\
\infty \\
0 \\
0\end{array}$ & \multicolumn{2}{|l|}{ m̋́ } \\
\hline & & 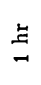 & $\begin{array}{l}00 \\
00 \\
0\end{array}$ & $\begin{array}{l}m \\
00 \\
0\end{array}$ & \multicolumn{2}{|l|}{$\begin{array}{l}0 \\
0 \\
0 \\
0\end{array}$} \\
\hline & & 亲 & $\begin{array}{l}20 \\
0 \\
0 \\
0\end{array}$ & 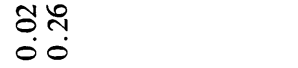 & \multicolumn{2}{|l|}{$\begin{array}{l}8 \% \\
00 \\
0\end{array}$} \\
\hline & \multicolumn{2}{|c|}{ 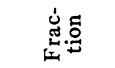 } & $n 3^{\pi}$ & $\cos 3$ & \multicolumn{2}{|l|}{$n 3^{\pi}$} \\
\hline \multirow{10}{*}{ 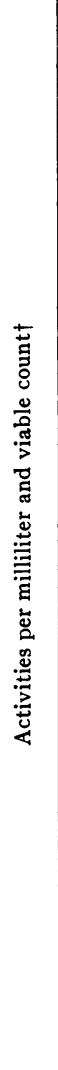 } & \multirow{2}{*}{ 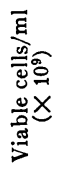 } & $\stackrel{\breve{s}}{\sharp}$ & $\ddot{n}$ & $\stackrel{\circ}{m}$ & \multicolumn{2}{|l|}{$\tilde{i}$} \\
\hline & & 章 & $\bar{\sigma}$ & $\dot{m}$ & \multicolumn{2}{|l|}{$\stackrel{\circ}{\dot{\sigma}}$} \\
\hline & \multirow{3}{*}{ 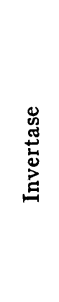 } & $\stackrel{\sharp}{g}$ & $\stackrel{0}{\dot{q}}|\stackrel{\sim}{\tilde{N}}| \hat{\sigma} \mid \stackrel{a}{-}$ & $\stackrel{0}{\dot{\theta}}|\stackrel{\dot{\delta}}{\infty}| \stackrel{0}{i}|\stackrel{r}{r}| \stackrel{+}{-}$ & \multicolumn{2}{|c|}{$\begin{array}{l}00000 \\
0 \dot{0} 00 \\
0\end{array}$} \\
\hline & & $\stackrel{\underline{E}}{=}$ & 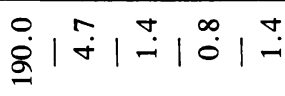 & $\stackrel{0}{\stackrel{0}{\hat{N}}}|\stackrel{\infty}{\infty}| \stackrel{0}{\infty}|\stackrel{0}{\infty}| \stackrel{\dot{m}}{ } \mid \stackrel{\infty}{0}$ & \multicolumn{2}{|c|}{ 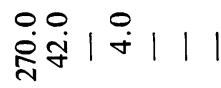 } \\
\hline & & 䒹 & $\stackrel{0}{\dot{\leftrightarrow}}|\stackrel{0}{0}| \stackrel{+}{-}|\stackrel{m}{0}|^{\infty}$ & $\stackrel{0}{0}|\stackrel{m}{0}| \stackrel{\infty}{0}|\tilde{n}| \stackrel{m}{0}$ & \multicolumn{2}{|c|}{ 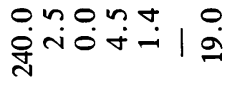 } \\
\hline & \multirow{3}{*}{ 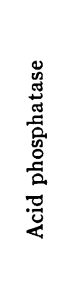 } & $\stackrel{\sharp}{s}$ & 它 & 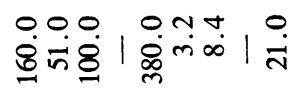 & \multicolumn{2}{|c|}{ 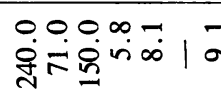 } \\
\hline & & 占 & 움우 & 我是| & \multicolumn{2}{|c|}{ 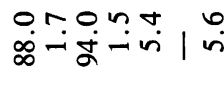 } \\
\hline & & 兮 & 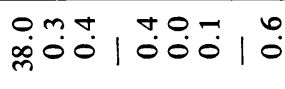 & 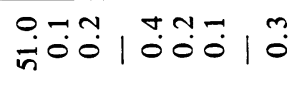 & \multicolumn{2}{|c|}{ 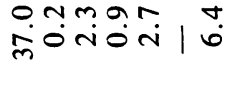 } \\
\hline & \multicolumn{2}{|c|}{ 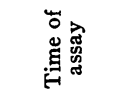 } & ロルールールロル & ーIルエーIロI & \multicolumn{2}{|c|}{ ーエールール } \\
\hline & \multicolumn{2}{|c|}{ 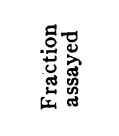 } & $\begin{array}{cccc}3 & - & 3 & 1 \\
u+ & + & + & + \\
3 & n & 3 & 3\end{array}$ & $\begin{array}{cccc}3 & - & 3 & H \\
u+ & + & + & + \\
3 \text { n } & \text { n } & 3 & 3\end{array}$ & $\sum_{n}$ & $\begin{array}{ll}3 & H \\
+ & + \\
3 & 3\end{array}$ \\
\hline & 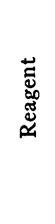 & & & $\begin{array}{l}\Sigma \\
\stackrel{0}{-} \\
\overrightarrow{0} \\
\ddot{v}\end{array}$ & \multicolumn{2}{|l|}{ 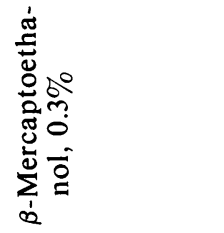 } \\
\hline
\end{tabular}




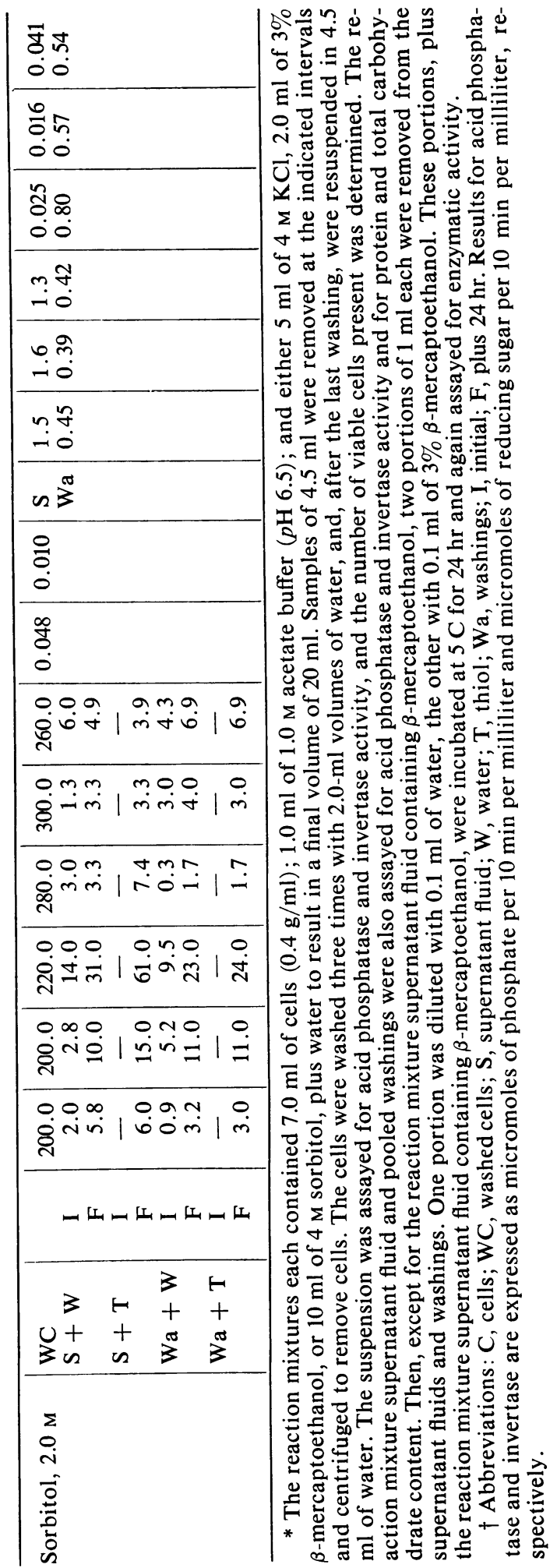


was not altered sufficiently by either $1.0 \mathrm{M} \mathrm{KCl}$ or $0.3 \% \beta$-mercaptoethanol to permit elution of either of the two exocellular enzymes by water (Table 5). Continued incubation in the presence of these reagents was needed to separate the enzymes from the cells.

To compare the effect of a neutral compound on $S$. fragilis cells with that of sucrose on $E$. coli, the yeast cells were suspended in $2 \mathrm{M}$ sorbitol. Sucrose could not be used since the cells contained invertase. This concentration of sorbitol killed the cells (Table 5), probably by destroying cell permeability. Microscopic examination of cells suspended in $2 \mathrm{M}$ sorbitol showed them to be dehydrated just as were cells suspended in $1 \mathrm{M}$ $\mathrm{KCl}$. However, unlike cells treated with $\mathrm{KCl}$, sorbitol-treated cells did not regain a turgid appearance when centrifuged and resuspended in water.

Both invertase and acid phosphatase were extracted by washing sorbitol-treated cells with water, but not in very large quantities when compared with the amount remaining attached to the cells. Since cellular permeability appears to be adversely affected, it cannot be concluded that enzymes in the washings are of exocellular origin only.

Elution of acid phosphatase and invertase from $S$. cerevisiae. Previous studies have shown that both invertase and acid phosphatase are repressible enzymes in $S$. cerevisiae and are exocellular $(3,7,9,16)$. Although there is a similarity be-

TABLE 6. Conditions for eluting exocellular enzymes from Saccharomyces cerevisiae*

\begin{tabular}{|c|c|c|c|c|c|}
\hline \multirow{2}{*}{ Reaction mixture } & \multirow{2}{*}{$\begin{array}{l}\text { Time of } \\
\text { sampling }\end{array}$} & \multicolumn{2}{|c|}{ Acid phosphatase $\dagger$} & \multicolumn{2}{|c|}{ Invertase } \\
\hline & & Cells & $\begin{array}{l}\text { Supernatant } \\
\text { fluid }\end{array}$ & Cells & $\begin{array}{l}\text { Supernatant } \\
\text { fluid }\end{array}$ \\
\hline Complete & \begin{tabular}{r}
\multicolumn{1}{c}{$r$} \\
0 \\
6 \\
12 \\
24
\end{tabular} & $\begin{array}{r}17.0 \\
8.8 \\
2.0 \\
2.6\end{array}$ & $\begin{array}{r}1.6 \\
3.8 \\
13.0 \\
1.6\end{array}$ & $\begin{array}{r}1,600.0 \\
710.0 \\
310.0 \\
280.0\end{array}$ & $\begin{array}{r}5.0 \\
80.0 \\
460.0 \\
470.0\end{array}$ \\
\hline Complete minus thiol & $\begin{array}{r}0 \\
6 \\
12 \\
24\end{array}$ & $\begin{array}{r}17.0 \\
12.0 \\
8.7 \\
7.7\end{array}$ & $\begin{array}{l}1.4 \\
2.0 \\
4.0 \\
3.1\end{array}$ & $\begin{array}{r}1,500.0 \\
1,100.0 \\
940.0 \\
650.0\end{array}$ & $\begin{array}{r}6.0 \\
92.0 \\
190.0 \\
460.0\end{array}$ \\
\hline Complete minus $\mathrm{KCl}$ & $\begin{array}{r}0 \\
6 \\
12 \\
24\end{array}$ & $\begin{array}{l}16.0 \\
17.0 \\
11.0 \\
11.0\end{array}$ & $\begin{array}{l}1.1 \\
2.4 \\
4.0 \\
4.3\end{array}$ & $\begin{array}{r}1,400.0 \\
1,100.0 \\
900.0 \\
590.0\end{array}$ & $\begin{array}{r}5.5 \\
88.0 \\
200.0 \\
450.0\end{array}$ \\
\hline Complete minus snail fluid & $\begin{array}{r}0 \\
6 \\
12 \\
24\end{array}$ & $\begin{array}{l}16.0 \\
17.0 \\
16.0 \\
14.0\end{array}$ & $\begin{array}{l}0.0 \\
0.2 \\
0.1 \\
0.3\end{array}$ & $\begin{array}{l}1,400.0 \\
1,100.0 \\
1,300.0 \\
1,100.0\end{array}$ & $\begin{array}{r}3.7 \\
18.0 \\
20.0 \\
62.0\end{array}$ \\
\hline Complete minus $\mathrm{KCl}$ and thiol & $\begin{array}{r}0 \\
6 \\
12 \\
24\end{array}$ & $\begin{array}{l}17.0 \\
17.0 \\
16.0 \\
16.0\end{array}$ & $\begin{array}{l}1.3 \\
1.6 \\
1.9 \\
2.4\end{array}$ & $\begin{array}{l}1,500.0 \\
1,100.0 \\
1,100.0 \\
1,100.0\end{array}$ & $\begin{array}{r}5.0 \\
50.0 \\
57.0 \\
950\end{array}$ \\
\hline $\begin{array}{l}\text { Complete minus } \mathrm{KCl} \text {, thiol, and } \\
\text { snail fluid }\end{array}$ & $\begin{array}{r}0 \\
6 \\
12 \\
24\end{array}$ & $\begin{array}{l}16.0 \\
17.0 \\
16.0 \\
16.0\end{array}$ & $\begin{array}{l}0.2 \\
0.2 \\
0.2 \\
0.5\end{array}$ & $\begin{array}{l}1,600.0 \\
1,100.0 \\
1,300.0 \\
1,200.0\end{array}$ & $\begin{array}{r}7.5 \\
11.0 \\
22.0 \\
37.0\end{array}$ \\
\hline
\end{tabular}

* A complete reaction mixture consists of $2.5 \mathrm{ml}$ of cells $(0.4 \mathrm{~g} / \mathrm{ml}), 0.25 \mathrm{ml}$ of $1.0 \mathrm{M}$ acetate $(p \mathrm{H} 5.5)$, $0.25 \mathrm{ml}$ of $3 \% \beta$-mercaptoethanol, $1.25 \mathrm{ml}$ of $4 \mathrm{M} \mathrm{KCl}, 0.5 \mathrm{ml}$ of snail gut fluid, and $0.25 \mathrm{ml}$ of water. In the other reaction mixtures, the ingredient omitted was replaced with an equal volume of water. At the intervals indicated, $1.0-\mathrm{ml}$ samples were removed and centrifuged, and the cells were resuspended in $1.0 \mathrm{ml}$ of water. The cells and supernatant fluids were assayed for acid phosphatase and invertase activity.

$\dagger$ Expressed as micromoles of phosphate per $10 \mathrm{~min}$ per milliliter.

$\ddagger$ Expressed as micromoles of reducing sugar per 10 min per milliliter. 
tween the enzymes on $S$. cerevisiae and those on $S$. mellis and $S$. fragilis to this degree, $S$. cerevisiae responded differently to salt and thiol treatment than did either of the other two organisms.

Physiological age did not seem to be an important factor for $S$. cerevisiae as long as cells were in the maximal stationary phase of growth. Therefore, not such great care was exercised in handling this organism as in handling $S$. fragilis. Neither $\mathrm{KCl}$ at concentrations ranging up to $2 \mathrm{M}$ nor $\beta$-mercaptoethanol at concentrations as high as $1 \%$, nor mixtures of these reagents, eluted acid phosphatase from resting cells of $S$. cerevisiae under the same conditions that were effective for $S$. fragilis. Salt did not extract any invertase from the cells, although $\beta$-mercaptoethanol did elute approximately $2 \%$ of the total cellular activity during $4 \mathrm{hr}$ of incubation. Assay of the extracts for protein and carbohydrate revealed that both reagents eluted negligible amounts of carbohydrate, and that protein was extracted in small amounts by thiol only $[0.3 \mathrm{mg}$ of protein from $120 \mathrm{mg}$ (wet weight) of cells]. As reported previously for growing cells $(1,9,16)$, it was necessary to treat resting cells of $S$. cerevisiae with snail gut fluid to release enzymatic activity from the cells.

Appreciable amounts of both acid phosphatase and invertase were eluted when the cells were treated with snail fluid in combination with $\mathbf{K C l}$ and $\beta$-mercaptoethanol (Table 6 ). The rate of elution was highest between the 6th and 12th hr of incubation. This corresponded to the period in which the cells were being converted into protoplasts, as determined by microscopic observation. In other reaction mixtures which contained resting cells and snail fluid but lacked either $\mathrm{KCl}$ or $\beta$-mercaptoethanol, only a small percentage of the cells had apparently been converted to protoplasts after $24 \mathrm{hr}$ of incubation, and these were unstable and had lysed. As determined by packed volumes when the cells were removed from the reaction mixtures by centrifugation, well over $85 \%$ of the cells added initially were still not osmotically fragile. Yet, as much invertase was eluted in $24 \mathrm{hr}$ under these conditions as had been eluted in $12 \mathrm{hr}$ under conditions where protoplasts may be formed. It should be noted that these same conditions were not adequate for the release of much more than $25 \%$ of the acid phosphatase activity on the cells. It would appear, then, that both exocellular enzymes require the action of snail gut fluid to be eluted, but that some proportion of invertase may be removed without the necessity of forming protoplasts.

The stability of enzyme attachment to the cell surface of $S$. cerevisiae resembles that of $S$. mellis because the enzymes were not dissociable from the cell by cold water after a period of exposure to $1 \mathrm{M} \mathrm{KCl,} 2 \mathrm{~m}$ sorbitol, or $0.3 \% \beta$-mercaptoethanol.

\section{Discussion}

It has been known for some time that cell walls of yeasts contain protein $(11,13)$. Protein that is tightly complexed with carbohydrate has been isolated from cell walls of baker's yeast. However, the method of isolation was so drastic that it provided no information regarding its mode of attachment to the wall. Weimberg and Orton (20) reported that it was possible to remove protein and carbohydrate from intact cells of a different yeast, $S$. mellis, under conditions that did not affect viability. The reagents required for extraction suggested that the protein was attached to the wall by a combination of electrostatic forces and disulfide bonds. Since a portion of this extracted material was the enzyme acid phosphatase, at least this part was in the same native form as it exists on the cell.

This type of study was extended to two different yeasts. The results obtained with $S$. fragilis and $S$. cerevisiae were different from each other and from those obtained with $S$. mellis. In $S$. fragilis, two exocellular enzymes, invertase and acid phosphatase, may be dissociated from the cells even in dilute buffer, but the addition of either $\beta$-mercaptoethanol or salt to the reaction mixture greatly accelerates the rate of dissociation. The course of events of enzyme dissociation will vary according to the physiological age of the organism. These enzymes are held fairly tightly to the cell during cellular growth. At this stage, it is necessary to digest the cell wall to remove the enzymes. As the cells pass into the maximal stationary phase of growth, the mode of attachment must change since conditions for elution change. In aged cells, it is no longer necessary to digest the cell wall to dissociate the enzymes. Considerable amounts are eluted by incubating the cells in the presence of salt or thiol. It is even possible to remove some activity simply by washing the cells in dilute buffer. However, conditions for quantitative elution of enzymes were not found, and the results were not stoichiometric. There is no apparent relationship between the amount separated from the cells and that remaining attached. Davies and Elvin (2) have also reported an effect of $\beta$-mercaptoethanol on the production of protoplasts of $S$. fragilis and on the release of exocellular enzymes without protoplast formation. With the strain of $S$. fragilis used by these authors, invertase but not acid phosphatase was eluted by $\beta$-mercaptoethanol.

Acid phosphatase seems to be eluted from cells of $S$. fragilis in an inactive form, because eluates increase in activity when they are incubated sev- 
eral hours after removal of cells from the reaction mixtures. The activity may increase four- to fivefold over a $24-\mathrm{hr}$ period. In addition, the increase in activity is even greater if a thiol, like $\beta$-mercaptoethanol, or a reducing agent, such as cyanide, is added to the eluate. At the same time that acid phosphatase and invertase are being eluted from the cells, the amounts of these two enzymes remaining attached to the cell surface are increasing. The final amount found on the cell may be as much as several hundred per cent of that present initially. This change in detectable enzymatic activity on the cell surface is not completely dependent upon the presence of salt or thiol. It occurs even in their absence with cells that are incubated in just a lightly buffered solution. These results with intact cells may be interpreted in terms of de novo protein synthesis. However, since enzyme activity is increasing simultaneously both on the cells and in extracts under the same conditions, the mechanism involved in both cases is probably the same. Protein synthesis, therefore, would be ruled out as the explanation, because there is little possibility of such a reaction taking place in eluates. More likely, the enzymes are already present in the cell wall at the time of harvest, but only a portion of each is in an enzymatically active form. Then, as the cells are incubated, the "inactive" proteins are converted in some way into active enzymes. If the cells are treated with the eluting reagents the "inactive" protein is separated from the cell, and it also will undergo conversion to the functional enzyme form while in solution. Results similar to these have been reported for $S$. mellis (20). Bound acid phosphatase activity on acetone-dried cells of $S$. mellis increases when the preparation is treated with water of $\beta$-mercaptoethanol, but under these conditions no activity is eluted. Here again, since protein biosynthesis is not likely to occur in acetone-dried cells, the increased activity is probably due to a conversion of pre-existing "inactive" protein into an enzymatically active state.

Since the two exocellular enzymes studied in $S$. fragilis are eluted by either salt or thiol, the results are not definitive enough to permit any conclusions concerning the bonds by which they are attached to the cell surface. However, results obtained with $S$. fragilis resemble those obtained with $S$. mellis sufficiently (20) to suggest that the mode of attachment of exocellular enzymes in these two organisms is similar. On the other hand, attachment of exocellular enzymes to $S$. cerevisiae cells appears to be quite different. Neither protein nor carbohydrate is eluted from these cells by salt, and, consequently, enzymatic activity is not eluted. A small amount of invertase is eluted by $\beta$-mercaptoethanol, but no acid phosphatase. The association of the enzymes to the walls of $S$. cerevisiae is thus probably or a different type from that in $S$. mellis and $S$. fragilis. Also, each of the exocellular enzymes is attached to the walls of $S$. cerevisiae with varying degrees of firmness. Both enzymes can be dissociated from the cells by snail gut fluid but invertase is released without protoplast formation, whereas acid phosphatase is found in the soluble supernatant fluid only under conditions in which protoplasts are formed and at the time that protoplasts appear in the reaction mixture.

The enzymatic properties of the exocellular invertase and acid phosphatase of $S$. cerevisiae seem to differentiate them from those proteins which catalyze the same reactions in $S$. fragilis; however, this may not be related to the problem of protein attachment to yeast cell walls. The invertase of $S$. cerevisiae is a $\beta$-fructosidase with a higher degree of specificity than the invertase of $S$. fragilis (14). The $S$. cerevisiae acid phosphatase has a $p \mathrm{H}$ optimum around 3 , which is lower than the optimum of the $S$. fragilis enzyme of $p \mathrm{H} 6.5$.

Factors other than externally applied reagents like salts and thiols may be involved in releasing exocellular enzymes from yeast cells. For instance, Wickerham and Dworschack (22) found some correlation between the ability of $S$. kluyveri to excrete invertase and the ploidy of unisexuals. Although still unknown, there may be more factors effecting enzyme attachment, since Wickerham (21) and Dworschack and Wickerham $(4,5)$ found a number of different species of yeast that produce extracellular invertase to varying degrees. In these latter examples, there were no ingredients in the growth media that corresponded to the concentrations of salts or thiols used here.

\section{Literature Cited}

1. Burger, M., E. E. Bacon, and J. S. D. Bacon. 1961. Some observations on the form and location of invertase in the yeast cell. Biochem. J. 78:504-511.

2. Davies, R., AND P. A. Elvin. 1964. The effect of $\beta$-mercaptoethanol on release of invertase and formation of protoplasts of Saccharomyces fragilis. Biochem. J. 93:8-9.

3. Dodyk, F., AND A. RothsteIn. 1964. Factors influencing the appearance of invertase in Saccharomyces cerevisiae. Arch. Biochem. Biophys. 104:478-486.

4. Dworschak, R. G., AND L. J. Wickerham. 1958. Production of extracellular invertase by the yeast, Saccharomyces uvarum NRRL Y-972. Arch. Biochem. Biophys. 76:449-456.

5. DWORSChack, R. G., AND L. J. Wickerham. 1961. Production of extracellular and total invertase by Candida utilis, Saccharomyces cerevisiae, and other yeasts. Appl. Microbiol. 9:291-294. 
6. Hassid, W. Z., and S. Abraham. 1957. Chemical procedures for analysis of polysaccharides, p. 34-50. In S. P. Colowick and N. O. Kaplan [ed.], Methods in enzymology, vol. 3. Academic Press, Inc., New York.

7. Heredia, C. F., F. Yen, ANd A. Sols. 1963. Role and formation of the acid phosphatase in yeast. Biochem. Biophys. Res. Commun. 10:14-18.

8. Lowry, O. H., N. J. Rosebrough, A. L. FarR, AND R. J. RANDALL. 1951. Protein measurement with the Folin phenol reagent. J. Biol. Chem. 193:265-275.

9. McLellan, W. L., JR., AND J. O. Lampen. 1963. The acid phosphatase of yeast. Localization and secretion by protoplasts. Biochim. Biophys. Acta 67:324-326.

10. Neu, H. C., AND L. A. Heppel. 1964. On the surface localization of enzymes in $E$. coli. Biochem. Biophys. Res. Commun. 17:215-219.

11. Nickerson, W. J. 1963. Symposium on biochemical bases of morphogenesis in fungi. IV. Molecular bases of form in yeasts. Bacteriol. Rev. 27:305-324.

12. Park, J. T., AND M. J. Johnson. 1949. A submicrodetermination of glucose. J. Biol. Chem. 181:149-151.

13. Phaff, H. J. 1963. Cell wall of yeasts. Ann. Rev. Microbiol. 17:15-30.

14. SNYDER, H. E., AND H. J. Phaff. 1960. Studies on a beta-fructosidase (inulinase) produced by Saccharomyces fragilis. Antonie van Leeuwenhoek J. Microbiol. Serol. 26:433-452.
15. Snyder, H. E., and H. J. Phaff. 1962. The pattern of action of inulinase from Saccharomyces fragilis on inulin. J. Biol. Chem. 237: 2438-2441.

16. Sutton, D. D., AND J. O. LAmpen. 1962. Localization of sucrose and maltose fermenting systems in Saccharomyces cerevisiae. Biochim. Biophys. Acta 56:303-312.

17. TAussky, H. A., AND E. SHORR. 1953. A microcolorimetric method for the determination of inorganic phosphorus. J. Biol. Chem. 202:675685 .

18. Weimberg, R., AND W. L. Orton. 1963. Repressible acid phosphomonoesterase and constitutive pyrophosphatase of Saccharomyces mellis. J. Bacteriol. 86:805-813.

19. WeimberG, R., AND W. L. OrTon. 1964. Evidence for an exocellular site for the acid phosphatase of Saccharomyces mellis. J. Bacteriol. 88:17431754.

20. WeimberG, R., AND W. L. ORTON. 1965. Elution of acid phosphatase from the cell surface of Saccharomyces mellis by potassium chloride. J. Bacteriol. 90:82-94.

21. Wickerham, L. J. 1958. Evidence of the production of extracellular invertase by certain strains of yeasts. Arch. Biochem. Biophys. 76:439-448.

22. Wickerham, L. J., AND R. G. DWORSChack. 1960. Extracellular invertase production by sexually agglutinative mating types of Saccharomyces kluyveri. Science 131:985-986. 